\title{
Legal Support of Interested-Party Transactions in the System of Corporate Social Responsibility
}

\author{
Kremleva O.K. \\ St. Petersburg State University of Economics, \\ Saint Petersburg, Russia \\ okremlev@mail.ru \\ Sviridov Ya.S \\ St. Petersburg State University of Economics, \\ Saint Petersburg, Russia
}

\author{
Rodionova T.N. \\ St. Petersburg State University of Economics, \\ Saint Petersburg, Russia
}

\author{
Kokorin I.S. \\ Leningrad State University named after A.S. Pushkin, \\ Saint Petersburg, Russia
}

\author{
Kovaleva G.V. \\ St. Petersburg State University of Industrial Technologies and Design, \\ Saint Petersburg, Russia
}

\begin{abstract}
The article presents a new approach to interestedparty transactions as a legal mechanism that includes elements of its functioning, namely, preliminary measures and measures of subsequent legal protection. Designing legal regulation on the issue of interested-party transactions is discussed. It is revealed that the factors in the formation of this legal mechanism are the institutional environment, political, and legal foundations. The authors suggest an optimal model of legal regulation of interestedparty transactions. The research purpose is to solve the problems of legal support for counteracting the withdrawal of assets by improving the legal mechanism for regulating interested-party transactions through the use of legal CSR tools. During the research, the authors follow the functional and instrumental approaches and use the methodology of economic analysis of law. Within the framework of these approaches to the study of legal phenomena, philosophical methods (dialectical, metaphysical, analytical), general scientific (analysis, synthesis, abstraction, generalization, induction, deduction), special scientific (formal legal, legal modeling, synergetic) are used. The researchers conclude that the identification of the relationship between the institutions for regulating interested-party transactions and CSR, as well as the influence of this relationship on the business reputation of commercial corporations contributes to the improvement of the legal mechanism of interested-party transactions. In the short and especially long term, increased attention to improving the legal mechanism of interested-party transactions and the voluntary implementation of the principles of its functioning by potentially interested parties of corporations will positively affect not only the business reputation of subjects of social and economic relations in regards to the CSR tasks implementation, but will also improve their financial and economic indicators.
\end{abstract}

Keywords - information disclosure; approval of the transaction, invalidity of an interested-party transaction, corporate social responsibility, prevention of corporate conflicts, formation of the corporation business reputation.

\section{INTRODUCTION}

During the COVID-19 pandemic, the problem of social sustainability and economic development has clearly aggravated. Thus, according to the baseline forecast, global GDP will contract by 5.2 percent in 2020, which, according to the World Bank, is an indicator of the "deepest recession" in recent decades, despite the efforts of states to counteract the economic downturn through fiscal and monetary policies. At the same time, the reasons for the long-term nature of such a recession are a decrease in investment, a fragmentation of global trade and supply chains.

Obviously, in order to preserve the business during the sharp changes in the structure of markets, the owners are forced to restructure it, optimize the activities of the organization, i.e. to reduce costs, as well as to change business strategy. In such a situation, ensuring the legitimate rights and interests of minority shareholders (participants of commercial corporations) and corporate employees becomes especially relevant, since both managers and majority shareholders, as follows from the wellknown "agency problem", tend to withdraw assets from the corporation for their own selfish purposes, especially in the context of the acute economic crisis.

\section{RESEARCH QUESTIONS}

- Identification of problems to be solved by improving the legal mechanism of interested-party transactions in the formation of this mechanism.

- Implementation of the potential of the legal mechanism 
of interested-party transactions in increasing the stability of intra-corporate relations by coordinating the relationship between this legal mechanism and the institution of corporate social responsibility (hereinafter - CSR).

- Application of CSR to improve the efficiency of legal regulation of interested-party transactions of commercial corporations and increase the investment attractiveness of the Russian economy both in the short term (at the post-COVID-19 stage) and in the long term.

\section{RESEARCH PURPOSE}

The research purpose is to solve the problems of legal support for counteracting the withdrawal of assets by improving the legal mechanism for regulating interested-party transactions through the use of legal CSR tools.

\section{RESEARCH METHODS}

When working over the problem "Identifying the tasks that can be solved by improving the legal mechanism of interestedparty transactions in the formation of this mechanism", a functional approach and methodology of economic analysis of law are used. There is a detailed description of the factors that determine the choice of the effective regime of legal regulation of interested-party transactions by regulators, taking into account the structure of the legal mechanism of interested-party transactions. The analysis of the positions presented in the literature sources serves as the basis for determining the goal and directions of the implementation of legal policy on the regulation of interested-party transactions.

Implementing the potential of the legal mechanism for regulating interested-party transactions in increasing the stability of intra-corporate relations is carried out through the coordination of relationship between the legal structures of interested-party transactions and CSR, i.e. the use of the CSR institution to increase the efficiency of legal regulation of interested-party transactions of commercial corporations with the help of an instrumental approach to law and economic analysis of law methods. Thus, the authors identify the motivation for Russian corporations' compliance with the norms of socially responsible behavior; the level of demand for corporate rationing in the socio-economic sphere; the risks, benefits, and advantages that corporations get if they comply with CSR standards; the degree of increased stability of intra corporate relations; the growth of the investment attractiveness of corporations.

Within the framework of these approaches to the study of legal phenomena, philosophical methods (dialectical, metaphysical, analytical), general scientific (analysis, synthesis, abstraction, generalization, induction, deduction), special scientific (formal legal, legal modeling, synergetic) are used.

\section{V.DISCUSSION AND RESULTS}

The issue of choosing an effective mode for legal regulation of interested-party transactions is determined not only by purely legal aspects, but by other, first of all, socio-economic factors (corporate governance structure, actual business environment, etc.) existing in a particular economy [1], as well as, in a broader sense, by the institutional environment [2]. In general, we are talking about the choice of the subject and method of legal regulation that affect the legislator's definition of the subject area of the key interests of the state and economic entities, which are taken into account when designing legal regulation of the institution of interested-party transactions.

Reaching the balance between imperative and dispositive regulation is especially relevant for influencing the legal mechanism for implementing interested-party transactions, since a change in the proportion in a combination of methods immediately forms favorable or unfavorable conditions, which hinder the development of the corporation, as well as creates the effect of reducing and (or) increasing the rate of return for various categories of participants in intra-corporate relations.

Besides, there are also political and legal reasons for the appearance of this or that model of interested-party transactions regulation. A comparative legal study of the legal institution of interested-party transactions in the legal systems of the USA, Great Britain, France, Germany, Italy, Spain, Finland, and Poland, allows making a conclusion that "tolerance" towards interested-party transactions and economic development are interrelated. New firms (start-ups) are most prone to making transactions with an interest, since "transactions between independent participants (arm's length transactions) are not always available to unverified firms" [3]. There is also a wellgrounded opinion that the "soft option" of regulating interestedparty transactions and the execution of provisions on such transactions throughout the world is "equivalent to the implicit legalization of the extraction of material private benefits" through such transactions [2].

Therefore, the mode of legal regulation of interested-party transactions in a specific legal system cannot be created in isolation from the above-mentioned socio-economic and political factors characteristic of a given country. It is known that the positive effects of an interested-party transaction can include "reduction of transaction costs, efficient creation and distribution of resources within the group (companies), maintaining an important but less profitable business", etc. Obviously, the major negative effect of transactions with interested parties is the withdrawal of assets from the corporation by insiders (controlling persons) and management [4].

Considering the economic consequences of an interestedparty transaction for corporations and participants, legal scholars put forward two opposite hypotheses: the conflict of interest of interested-party transactions and their effectiveness. Accordingly, the first approach presupposes the legislative limitation of interested-party transactions and their strict control. From another point of view, such a model of legal regulation would be detrimental to the financial activities of a commercial corporation, since there are interested-party transactions that are made in the "best interests of the company" and therefore are legitimate per se.

It would seem obvious that an intermediate approach should be taken, that is to prohibit unprofitable interested-party transactions and to allow transactions that do not entail damage to the legal entity, rather than to prohibit interested-party transactions at all. However, in this case, the difficult question arises of how in practice the members of the corporation, members of its board of directors or regulators can determine which related-party transactions are profitable for the corporation and which are not [5], especially in the long term and in regards to accounting transactions on the results of the 
financial year made by the corporation in aggregate. A transaction that, at first glance, looks like it was made in the personal interests of the controlling person or a member of the management body, could be not a transaction of the kind, but, on the contrary, the person interested in the transaction could positively contribute to ensuring the corporation performance in the long run if the personal experience and developed connections of the decision maker are used.

The legal mechanism for interested-party transactions consists of the following elements:

- preliminary measures (preliminary information disclosure and the transaction approval);

- measures of subsequent legal protection (recovery of damages, recognition of an interested-party transaction as invalid, subsequent information disclosure).

The use of this mechanism is important for investors who assess to what extent they are able to control the activities of the corporation, and, in fact, whether by studying interested-party transactions, they can block unprofitable ones by voting. Thus, the specified legal mechanism is manifested in the effective implementation of preliminary measures and subsequent methods of legal protection used in critical cases of the corporation and its members.

At the same time, in accordance with international experience, the most important in this mechanism are precisely ex ante measures. "A stronger board structure reduces the likelihood of expropriation in related-party transactions" [6].

As the world experience shows, the next stage of the mechanism for protecting the rights of participants and corporations when making interested-party transactions is the procedures for regulation and approval after the identification of such transactions.

As it was noted earlier, there are interested-party transactions that are profitable both for the corporation and its members. Accordingly, the question arises of how to ensure the execution of such transactions on market conditions. Obviously, it is necessary at the regulatory level to provide persons authorized to make corporate decisions and control the activities of the corporation with the rights to analyze and approve interested-party transactions. Consolidation of rights is possible according to three models - courts (ex post investigation of interested-party transactions), shareholders and directors (ex ante approval of interested-party transactions). As an extension of the dispositiveness of the legal regulation of the interested-party transactions institution, one can offer the corporation members a choice from the proposed set of models, as well as a two-stage or mixed model.

Ensuring the stability of corporate relations should be sought not only directly in positive law, but also in legal regulation on the issue of increasing economic and other incentives for business decision makers (insiders). One should consider the CSR toolkit, which leads to an increased efficiency of legal regulation of the legal mechanism of interested-party transactions through the performance of socially significant corporation functions during a pandemic that entailed a deeper economic crisis by the members of the corporation's governing bodies, majority shareholders, and the controlling persons of the organization; interaction with stakeholders will also have a positive impact on financial results, it will promote the goal of sustainable economic development, as well as create "a positive image of a corporate citizen" [7]. It is not correct to believe that CSR lies outside the scope of legal requirements [8], since, as noted in the same study, CSR includes four elements: economic, legal, ethical, and charitable.

CSR was institutionalized in 1992 with the creation of the International Association "Business for Social Responsibility", the mission of which was to work with business in order to create a fair and sustainable world [9]. For many decades, researchers of corporate social responsibility have associated it with the principles of sustainable development, which means that organizations are obliged to make decisions taking into account the short-term and long-term social, environmental and other consequences of their activities. It is noted that "improved environmental and social performance does lead to higher levels of financial performance". However, at the same time, this position is controversial: it is difficult to speak of an unconditional positive relationship between increased attention to compliance with social responsibility standards and the growth of corporate financial performance due to the existence of factors that can, on the contrary, lead to a decrease in such indicators (for example, an excessive shift in the attention of management to improving environmental and social policy and its financing to the detriment of the key strategies of the corporation). Despite this, "the responsiveness of companies in relation to numerous stakeholders is consistent with their interests, it does not promise huge profits, but protects against sharp downturns" [10]. In addition, according to one of the theories of managing the interests of stakeholders called the "internal model of stakeholder obligations", corporations are sometimes interested not only in maximizing profits, but also in taking moral obligations [11].

The relationship between improving the financial performance of companies and its policy aimed at implementing socially responsible behavior has acquired a new and louder sound in the context of quarantine. In particular, according to the Bank of America (BofA) Report, because of the current climate change, environmental degradation, cybersecurity and inequality issues due to COVID-19, "longterm government policy on trade and economic incentives, as well as corporate strategy on sourcing, will take security and climate change into account more seriously than in the past"; it will entail greater investors' attention to corporations that take long-term risks into account and are therefore more reliable [12]. Moreover, "stakeholders are concerned that the company they support has business practices which positively influence society in achieving financial success" [13].

Introduction of the legal institution of CSR into the Russian legal system results in the most effective ex ante execution of the element of the legal mechanism of interested-party transactions implementation, which, as noted above, plays a key role in ensuring the stability of intra-corporate relations. Managers and controlling persons who are interested not only in increasing the value of the corporation and in receiving higher wages and/or dividends, but also in improving social and environmental performance of the corporation will be more responsible for their business decisions, as well as for making and approving interested-party transactions. Recent studies have shown that the more a corporation publically reports on its CSR compliance over a certain period, the more pronounced the relationship between sales of the corporation through interested-party transactions and the value of the corporation 
becomes, which entails a decrease in the risk of opportunistic behavior of members of management bodies and other persons who actually control corporation, since CSR reporting reflects the desire to be more ethical and credible [14].

The development of corporate social responsibility in Russia helps to increase the investment attractiveness of the national economy. Thus, according to the report of the international firm EY on the results of 2019, Russia is ranked ninth among the ten most attractive countries for European investors. At the same time, "the overall indicator of the number of foreign direct investment projects in the Russian economy is quite high", if we take into account the global slowdown in economic growth and the ongoing sanctions [15]. By stimulating Russian corporations to develop CSR, Russian regulators can significantly affect the improvement of the investment climate of the Russian economy by increasing ESG (Environmental, Social, and Governance) - an investment that assumes that investors take into account how the corporation's values correspond to their own.

\section{SUMMING UP}

Conceptually, the legal regulation of interested-party transactions should fulfill two important tasks: firstly, to consolidate a significant difference between legitimate business decisions and transactions in personal (illegal) interests; secondly, to establish appropriate mechanisms to regulate such transactions. Among the stages of its implementation can be distinguished preliminary (ex ante) and subsequent (ex post) stages.

The mechanism for regulating interested-party transactions in business companies occupies one of the central places in the legal regulation of the protection of minority participants (shareholders) from illegal actions of members of management bodies and major participants (shareholders), namely the withdrawal of assets from an organization to a controlled person.

In a situation of social and economic instability, including the one that appeared during the extreme period of the COVID19 pandemic, ensuring the legitimate rights and interests of minority shareholders (and members of commercial corporations) comes to the fore. In order to stabilize intracorporate relations at a time of high risk of asset withdrawal from the organization, first of all, members of management bodies and controlling persons should normatively define the tools of corporate social responsibility in the legal mechanism of interested-party transactions. This legal mechanism stimulates the performance of socially significant functions of the corporation by members of the governing bodies of the corporation, majority shareholders, and controlling persons, also during a pandemic, which will also have a positive effect on the business reputation and financial results of commercial organizations and, ultimately, create incentives to reduce the risk of self-serving behavior by those interested in making unprofitable interested-party transactions.

There is a close relationship between the legal institutions of interested-party transactions and CSR. Firstly, both legal institutions solve the problem of stabilizing corporate relations, with the difference that the legal mechanism of interested-party transactions solves it "within" the corporation, while CSR acts "from the outside", because the interests of clients, corporation employees, etc., who are not shareholders, do not belong to corporate interests, but are "outside" the corporation being a subject of relations which are broader in content than exclusively legal and socio-economic ones. Secondly, information on both the facts of interested-party transactions and the implementation of socially responsible behavior by the corporation is the factor that affects the investment attractiveness of the corporation. Improvement of the legal mechanism of interested-party transactions actually contributes to an increase in the efficiency of the implementation of CSR goals [16].

\section{CONSCLUSION}

Revealing the relationship of institutions regulating interested-party transactions and CSR, as well as the influence of this relationship on the business reputation of commercial corporations, contributes to the improvement of the legal mechanism of corporate relations. In the short and especially long term, increased attention to improving the legal mechanism of interested-party transactions and the voluntary implementation of the principles of its functioning by potentially interested parties of corporations will have a positive effect not only on the business reputation of subjects of social and economic relations in the light of the implementation of CSR tasks, but also on the improvement of their financial and economic indicators.

\section{References}

[1] N. Moscariello, "Related Party Transactions in Continental European Countries: Evidence from Italy", International Journal of Disclosure and Governance, 2011. Retrieved from: https://www.researchgate.net/publication/228248086_Related_Party_Tra nsactions_in_Continental_European_Countries_Evidence_from_Italy?en richId=rgreq-d5ccc2c646a1f73dd98380e06f694210-

XXX\&enrichSource $=$ Y292ZXJQYWdlOzIyODI0ODA4NjtBUzoyMjY wNjg1MjgxNDQzODVAMTQzMDkxMDM0NTM4Mw\%3D\%3D\&el= $1 \_\mathrm{X} \_2 \& \_$esc $=$publicationCoverPdf

[2] L. Enriques, "Related Party Transactions: Policy Options and Real-World Challenges (With a Critique of the European Commission Proposal) (October 3, 2014)", European Corporate Governance Institute (ECGI) Law Working Paper vol. 267/2014. Retrieved from: https://ssrn.com/abstract=2505188 http://dx.doi.org/10.2139/ssrn.2505188

[3] D.G. Smith, "Duties of Nominee Directors" (2013), Paragraph 3 in "Part 1: Directors' Duties and Liability" in "Comparative Company Law: A Case-Based Approach", Edited by Mathias Siems and David Cabrelli, Published in North America (US and Canada) by Hart Publishing. Retrieved from:

https://books.google.ru/books?id=Z216BAAAQBAJ\&pg=PT78\&lpg=PT $78 \& d q=$ validation+of+related+party+transaction+in+france $\&$ source $=b l$ \&ots=ziPosWgPB5\&sig=ACfU3U28ECU2x_ssA5rueMo4JNh35grpZA $\& h l=r u \& s a=X \& v e d=2$ ahUKEwit_oXjj9DiAhUpi8MKHSP9D484ChDo ATACegQIBRAB\#v=onepage $\& \mathrm{q}=$ validation $\% 20$ of $\% 20$ related $\% 20$ part $\mathrm{y} \% 20$ transaction $\% 20$ in $\% 20$ france $\& \mathrm{f}=$ true

[4] Z.S. Maigoshi, R.A. Latif and H. Kamardin, "Related Party Transactions and Earnings Management", The European Proceedings of Social \& Behavioural Sciencies, ISSC 2016: international Soft Science Conference, 2016. Retrieved from: http://dx.doi.org/10.15405/epsbs.2016.08.8

[5] Z. Goshen and A. Hamdani, "Corporate Control and Idiosyncratic Vision (April 1, 2013)",. Columbia Law and Economics Working Paper, vol. 444; ECGI - Law Working Paper No. 206; Yale Law Journal, vol. 125, 2016. Retrieved from: https://ssrn.com/abstract $=2228194$ or http://dx.doi.org/10.2139/ssrn.2228194. pp. 606-608.

[6] S. Claessens and B. Yurtoglu, "Corporate Governance in Emerging Markets: A Survey”, Emerging Markets Review, 2012, vol. 15, pp. 1-33. DOI: $10.2139 /$ ssrn. 1988880

[7] M. Bhambu, "Corporate Social Responsibility: Mission Possible (March 22, 2015)". Retrieved from: https://ssrn.com/abstract $=2583366$ or http://dx.doi.org/10.2139/ssrn.2583366 
[8] R. Safarzad, E. Farahnaki and M. Farahbakhsh, "Corporate Social Responsibility", Theories and Models (September 3, 2016). Retrieved from: https://ssrn.com/abstract=2834200

[9] A. Carroll, "Corporate social responsibility (csr) and corporate social performance (csp). In R. Kolb (Ed.)", The SAGE encyclopedia of business ethics and society, vol. 1, pp. 746-754. Thousand Oaks,, CA: SAGE Publications, Inc. DOI: 10.4135/9781483381503.n265

[10] G. Serafeim, "The Role of the Corporation in Society: An Alternative View and Opportunities for Future Research" (May 27, 2013). Retrieved from: https://ssrn.com/abstract=2270579 http://dx.doi.org/10.2139/ssrn.2270579

[11] R. Ramachandran, "Theories of Stakeholder Management (February 24, 2019)". Retrieved from: https://ssrn.com/abstract $=3535087$ or http://dx.doi.org/10.2139/ssrn.3535087

[12] H. Israel, L. Kalns-Timans, F. Tran, P. Das and M. Briggs, "BofA SECURITIES", Covid-19 Investment Implications Series: The World After Covid Primer. Retrieved from: https://www.bofaml.com/content/dam/boamlimages/documents/articles/I D20_0467/the_world_after_covid.pdf
[13] R. Ramachandran, "Significant Changes in the Business in the Last 30 Years Due to Corporate Social Responsibility", DSA Corporate Social Responsibility Study Group at the Magdalene College, Cambridge University UK, June 17, 2008. Retrieved from: https://ssrn.com/abstract=1751602 http://dx.doi.org/10.2139/ssrn.1751602

[14] T.D. Hendratama, Z. Barokah, "Related party transactions and firm value: Themoderating role of corporate social responsibility reporting", China Journal of Accounting Research, 2020, vol. 13. Retrieved from: https://doi.org/10.1016/j.cjar.2020.04.002

[15] A. Khutko, Investment attractiveness of European countries for 2019 Retrieved from: https://www.ey.com/ru_ru/news/2020/07/ey-europeanattractiveness-survey-2019

[16] O.K. Kremleva, Y.S. Sviridov, S.B. Glushachenko, E.N. Didkovskaya, T.N. Rodionova, "Corporations' Responsibility Legal Regulation For Energy Efficiency And Land Protection”, European Proceedings of Social and Behavioural Sciences (EpSBS), 2019, vol. 93. pp. 763-769. 